\title{
Peningkatan Peran Wakil Presiden Melalui Keppres No. 121 Tahun 2000
}

\author{
Ni’matul Huda
}

\begin{abstract}
The issuance of the Presidential Decree No. 121, 2000 about sharing duties of the President to the vice president in conducting the techniques of managing daily govemmental affairs constitutes a real effort to optimize the vice president's role and ministerial works which have so far been considered very weak. However, this decree could be as waming signal for the vice presiden Megawati to prove her capability, whether or not she is able to run the government well.
\end{abstract}

\section{Pendahuluan}

Selama ini peran Wakil Presiden dalam sistem pemerintahan indonesia hampir dapat dikatakan seperti "ban serep", yang hanya akan berfungsi manakala Presiden berhalangan, baik sifatnya sementara maupun tetap. Meskipun demikian, selama Orde Baru, setiap kali bangsa indonesia akan menghadapi pemilihan Presiden maupun Wakil Presiden, bursa nama yang muncul berganti-ganti hanyalah untuk posisi Wakil Presiden. Sementara untuk posisi Presiden tidak ada satu fraksi pun di Majelis Permusyawaratan Rakyat (MPR) yang berani memunculkan nama selain Soeharto. Nama calon Wakil Presiden yang diusuikan oleh MPR pun harus dikonsultasikan terlebih dahulu dengan Presiden. Jadi, meskipun kedudukan Wakil Presiden selalu dijdentikkan dengan "ban serep", selalu saja orang berharap bahwa suatu saat Wakil Presiden akan mendapatkan kedudukan yang lebih strategis dalam pemerintahan. Hal itu terbukti ketika kedudukan Wakil Presiden dipegang B.J. Habibie, meskipun dalam waktu yang relatif pendek.

Peran yang agak besar terlihat ketika jabatan Wakil Presiden dipegang B.J Habibie. Ketika itu kepercayaan dunia internasional terhadap pemerintah Indonesia sudah mulai menurun dan tanda-tanda akan terjadi krisis sudah mulai nampak. Kalau selama ini tugas Wakil Presiden hanyalah membantu Presiden dalam melaksanakan tugasnya, memperhatikan secara khusus, menampung masalah-masalah yang perlu dan menyangkut bidang tugas kesejahteraan rakyat, serta melakukan pengawasan operasional 
pembangunan, maka ketika habibie menjabat sebagai Wakil Presiden terjadi perubahan yang cukup signifikan menyangkut tugas yang dilimpahkan kepadanya, yakni a) membantu Presiden dalam tugas percaturan global melalui berbagai organisasi dunia seperti PBB, GNP, APEC, OKl, G-15, G-8, ASEM dan ASEAN; b) menyerasikan pembangunan industri yang meliputi industri hulu dan hilir, industri berat, menengah, dan kecil, agro industri dan industri rumah tangga; c) turut membina persatuan dan kesatuan bangsa berdasarkan iman dan taqwa kepada Tuhan Yang Maha Esa. Peran yang lebih besar lagi terjadi ketika Presiden Soeharto lengser dari tampuk kekuasaan yang sudah 32 tahun ia kuasai. Turunnya Soeharto dan naiknya Habibie menggantikan Soeharto ketika itu menjadi kontroversi di tengah-tengah masyarakat khususnya berkaitan dengan pijakan yuridis yang dipakai untuk peralihan kekuasaannya.

Tuntutan yang sama muncul kembali ketika fraksi-fraksi di MPR khususnya fraksi yang memiliki jumlah suara terbanyak di MPR (FPDIP) menuntut diberdayakannya posisi Wakil Presiden dalam Pemerintahan. Tuntutan itu kemudian direspon positif oleh Presiden Abdurrahman Wahid, dan ketika menyampaikan jawaban atas pemandangan umum fraksi-fraksi atas progress report Presiden di MPR, Abdurrahman Wahid menyatakan akan memberikan tugas yang lebih besar kepada Wakil Presiden Megawati Soekarno Putri. Pernyataan Presiden itu kemudian memunculkan berbagai tanggapan positif dari berbagai fraksi yang ada di MPR, tetapi sekaligus juga menimbulkan kontroversi mengenai bentuk pengaturan pelimpahan tugas antara Presiden dan Wakil Presiden.
Sebagian besar fraksi di MPR menginginkan pelimpahan tugas itu dalam bentuk Keputusan Presiden (Keppres) dengan pertimbangan bahwa masalah pelimpahan tugas antara Presiden dan Wakil Presiden itu masalah intern Pemerintah dan wewenang Presiden, bukan wewenang MPR. Pengaturan tersebut kemudian menimbulkan implikasi yang menyebabkan perubahan sistem pemerintahan negara dari kuasi presidensial menjadi (kuasi) parlementer.

Pada akhir Sidang Tahunan MPR dicapai kata sepakat di antara Anggota Majelis bahwa pengaturan tentang pelimpahan tugas antara Presiden dan wakil Presiden tidak diatur dalam Ketetapan MPR, tetapi diserahkan kepada Pemerintah sepenuhnya. Rekomendasi MPR itu kemudian dikukuhkan kedalam Ketetapan MPR No. VIII/MPR/2000 tentang Laporan Tahunan Lembaga Tinggi Negara.

Belakangan muncul masalah baru ketika Kepres No.121 Tahun 2000 tentang penugasan Presiden kepada Wakil Presiden untuk Melaksanakan Tugas Teknis Pemerintahan Sehari-hari, menurut beberapa kalangan masyarakat dipandang kurang substansial dan sekedar basi-basi. Bagaimana sesungguhnya sistem pemerintahan Indonesia mengatur hubungan antara Presiden dan Wakil Presiden?

\section{Pengaturan dalam UUD 1945 dan Ketetapan MPR}

Batang Tubuh UUD 1945 dan Penjelasan UUD 1945 mengatur tentang kedudukan dan Tugas Presiden dan Wakil Presiden berturuturut di dalam Pasal 4 ayat (1) dan (2), Pasal 6 ayat (2), Pasal 7, Pasal 8, Pasal 9 dan Penjelasan UUD 1945 Butir IV. Pasal 4 ayat (1) 
berbunyi, "Presiden Republik Indonesia memegang kekuasaan pemerintahan menurut Undang-undang Dasar." Kemudian di dalam Pasal 4 ayat (2) dinyatakan, "Dalam melakukan kewajibannya Presiden dibantu oleh satu orang Wakil Presiden." Pasal 6 ayat (2) menyatakan "Presiden dan Wakil Presiden dipilih oleh Majelis Permusyawaratan Rakyat dengan suara yang terbanyak." Mekanisme pemilihan Presiden dan Wakil Presiden diatur lebih lanjut dalam ketetapan MPR No. VI/MPRI 1999 tentang tatacara pencalonan dan Pemilihan Presiden dan Wakil Presiden RI.

Di dalam Pasal 7 ditentukan, "Presiden dan Wakil Presiden memegang jabatannya selama masa lima tahun, dan sesudahnya dapat dipilih kembali dalam jabatan yang sama hanya untuk satu kali masa jabatan." Kemudian dalam Pasal 8 ditegaskan, "Jika Presiden mangkat, berhenti, atau tidak dapat melaksakan kewajibannya dalam masa jabatannya, ia diganti oleh wakil Presiden sampai habis waktunya." Pengaturan lebih lanjut tentang keadaan sebagaimana dijelaskan dalam Pasal 8 UUD 1945 diatur dalam Ketetapan MPR No. VII/MPR/1973 tentang Keadaan Presiden dan Wakil Presiden RI Berhalangan. Pasal 2 ayat (1) Tap MPR No. VII/MPR/1973 menyatakan sebagai berikut: "Dalam hal Presiden berhalangan tetap, maka ia digantikan oleh Wakil Presiden sampai habis masa' jabatannya." Pasal 3 ayat (1) menyata, "Dalam hal Presiden berhalangan sementara, maka Presiden menugaskan Wakil Presiden untuk melaksanakan' tugas-tugas Presiden". Kemudan di ayat (2)-nya ditegaskan, "Apabila dalam hal yang dimasud pada ayat (1) pasal ini, Wakil Presiden dalam keadaan berhalangan, maka Presiden menunjuk seorang Menteri untuk melaksanakan tugastugas Presiden."

Dari penegasan tersebut, nampak bahwa meski Wakil Presiden dan Menteri sama-sama pembantu Presiden, tetapi prioritas pertama apabila Presiden berhalangan ada pada Wakil Presiden. Itulah salah satu perbedaan kedudukan antara Wakil Presiden dengan Menteri-menteri yang diatur dalam ketatanegaraan Indonesia di samping perbedaan lainnya.'

Pasal 9 ayat (1) UUD 1945 (Perubahan. Pertama) menyebutkan, "Sebelum memangku

Perbedaan yang lain adalah: pertama, dalam hal pengangkatannya, Wakil Presiden diangkat dan diberhentikan oleh MPR, sehingga Presiden tidak dapat membehentikannya, sedangkat Menteri-menteri negara diangkat dan diberhentikan oleh Presiden, sehingga kedudukannya sangat tergantung pada Presiden. Kedua, oleh karena tidak ada penjelasan lebih lanjut dalam UUD 1945 tentang kedudukan Wakil Presiden, maka perkataan "dibantu" dalam hubungannya dengan kedudukan Presiden dapat ditafsirkan Wakil Presiden membantu Presiden dalam melaksanakan kewajibannya, baik sebagai kepala pemerintah maupun sebagai kepala negara (Pasal 4 ayat (2), Pasal 6 ayat (2)dan Pasal 7 UUD 1945). Berteda dengan Wakil Presiden, maka kedudukan para Menteri pembantu kepala pemerintahan dan bukan pembantu kepala negara (Pasal 17 UUD1945). Kefiga, Wakil Presiden membantu Presiden secara umum, sedangkan Menteri pembantu Presiden secara khusus melalui departemennnya masing-masing atau melalui bidang-bidang tertentu (Menteri Negara). Lihat dalam Ni'matul Huda. 1999. Hukum Tata Negara, Kajian Teoitis dan Yuridis Terhádap Konstitusi Indonesia. Pusat Studi Hukum FHUll dan Gama Media. Yogyakarta. Him. 104. 
jabatannya, Presiden dan Wakil Presiden bersumpah menurut agama, atau berjanji dengan sungguh-sungguh di hadapan Majelis Permusyawaratan Rakyat atau Dewan Perwakilan Rakyat..." Ayat (2) menyebutkan, "Jika Majelis Permusyawaratan Rakyat atau Dewan Perwakilan Rakyat tidak dapat mengadakan sidang, Presiden dan Wakil Presiden bersumpah menurut agama, atau berjanji dengan sungguh-sungguh di hadapan pimpinan Majelis Permusyawaratan Rakyat dengan disaksikan oleh pimpinan Mahkamah Agung."

Penjelasan UUD 1945 butir IV menegaskan bahwa "Presiden ialah penyelengggara pemerintahan negara tertinggi di bawah majelis. Dalam menjalankan pemerintahan negara kekuasaan dan tanggung jawab adalah di tangan Presiden (concentration of power and responsibility upon the Presiden). Kemudian di dalam ketetapan MPR No. IIII MPR/1978 tentang Kedudukan dan Hubungan tata Kerja Lembaga Tertinggi Negara dengan/ atau Antar Lembaga-lembaga Tinggi Negara, Pasal 8 ayat (1) ditegaskan, "Presiden ialah penyelenggara Kekuasaan Pemerintahan Negara Tertinggi di bawah Majelis, yang dalam melakukan kewajibannya dibantu oleh Wakil Presiden." Dilanjutkan ayat (2) nya menyatakan, "Hubungan kerja antara Presiden dan Wakil Presiden diatur dan ditentukan oleh Presiden dan Wakil Presiden."

Dari beberapa ketentuan tersebut di atas, tampak bahwa sistem pemerintahan Indonesia menganut sistem pemerintahan presidensiil. Sebagaimana dijelaskan oleh Soepomo, sistem UUD 1945 memang direka sedemikian rupa sehingga kekuasaan terpusat pada Presiden (concentration of power and responsibility upon the President) atau menurut ungkapan yang populer "executive heavy". Bahkan, dalam sidang Dokuritzu Zyunbi Chosa Kai, Supomo berkata:?

"...buat (penyelenggara pemerintahan) sehari-hari Presidenlah yang merupakan penjelmaan kedaulatan rakyat."

“... yang merupakan penjelmaan kedaulatan rakyat ialah Presiden, bukan Dewan Perwakilan Rakyat."

Belakangan ini muncul aspirasi politik yang menghendaki agar kekuasaan Presiden dikurangi, sehingga ada perimbangan kekuasaan (checks and balances) di antara lembaga-lembaga tinggi negara. Aspirasi itu kemudian direspon positif oleh angggota MPR dengan melakukan perubahan pertama dan kedua (amandemen I dan II) terhadap UUD 1945.

\section{Kedudukan Wakil Presiden}

Apabila kedudukan Wakil Presiden dihubungkan dengan lembaga MPR, jelas tergambar bahwa kedudukan Wakil Presiden berada di bawah Majelis. Tetapi jika dihubungkan dengan Presiden, maka kedudukan Wakil Presiden ada dua kemungkinan, (1) Kedudukannya sederajat dengan Presiden; (2) kedudukannya berada

${ }^{2}$ Harun Alrasid. Jabatan Presiden Rl, Sebuah Tinjauan Hukum Tafa Negara. Pidato Dies Rede pada Sidang senat Terbuka Dalam Rangka Dies Natalis Ke-56 Univesitas islam IndonesiaYogyakarta. Tanggal 8 November 1999. HIm. 14-15. 
di bawah Presiden. Kemungkinan pertama, dapat diketahui dari pendekatan yuridis terhadap Pasal 6 ayat (2), Pasal 7, Pasal 8, Pasal 9 UUD 1945 jo Pasal 7, Pasal 22; Pasal 24 dan Pasal 25 Ketetapan MPR No. VIMPR/ 1999. Dari Pendekatan tersebut dapat tersimpul bahwa antara Presiden dan Wakil Presiden tidak terdapat hirarkhi hubungan sebagai atasan terhadap bawahan, yang nampak hanya pembagian prioritas dalam melaksanakan kekuasaan pemerintahan, di mana Presiden pemegang prioritas pertama, sedang Wakil Presiden pemegang prioritas kedua. Apabila Presiden berhalangan (sementara/tetap), Wakil Presidenlah yang dengan sendirinya harus melakukan kekuasaan Presiden.

Kemungkinan kedua, dapat diketahui melalui penafsiran terhadap Pasal 4 ayat (2) jo Pasal 5 UUD 1945 jo Penjelasan Butir IV jo Ketatapan MPR No. III/MPR/1978 Pasal 8 ayat (1). Di sini ternyata Presiden adalah satusatunya penyelenggara pemerintahan negara yang tertinggi, yang membawa konsekuensi segala tangggung jawab mengenai penyelenggaraan pemerintahan negara yang tertinggi berada di tangan Presiden. Wakil Presiden tidak dapat bertindak sendiri, karena semata-mata merupakan pembantu Presiden yang tugas dan kewajibannya tergantung pada adanya pemberian dan atau pelimpahan kekuasaan dari Presiden.

\section{Keputusan Presiden No. 121 Tahun 2000}

Dalam pemandangan umum fraksi-fraksi di MPR, sebagian besar anggota MPR menilai kinerja Kabinet Persatuan di bawah kepemimpinan Abdurrahman Wahid dinilai sangat lamban dan lemah. Sebagian besar fraksi di MPR, utamanya dari fraksi PDIP, meminta supaya manajemen pemerintahan lebih ditingkatkan dengan memberdayakan posisi Wakil Presiden Megawati. Fraksi PDIP menginginkan pelaksanaan pembagian tugas antara Presiden dan Wakil Presiden ini diatur secara tertulis, dengan alasan bahwa selama ini proses pelimpahan atau pendelégasian tugas dari Presiden kepada Wakil Presiden hanya dilakukan secara lisan, sehingga tidak jelas proses pelaksanaan dan pertanggungjawabannya.

Selama periode Kabinet Persatuan Nasional, pembagian kerja tersebut sebenarnya pernah dilakukan, bahkan tidak hanya secara lisan, tapi juga secara tertulis. Dalam proses permasalahan di Irian Jaya Maluku dan Riau misalnya, Presiden pernah mengeluarkan Keppres №. 151 Tahun 1999 tertanggal 4 Desember 1999 tentang Tim Kerja Irian Jaya, Tim Kerja Maluku, dan Tim Kerja Riau. Dalam bagian konsiderans dari Keppres tersebut antara lain dinyatakan bahwa "... di samping tugas-tugas umum membantu Presiden dalam penyelenggaraan pemerintahan negara, Wakil Presiden juga ditugasi Presiden untuk secara khusus menangani penyelesaian beberapa masalah kewilayahan tertentu. ${ }^{\text {"3 }}$

${ }^{3}$ Forum Keadilan. No. 20. 20Agustus 2000. Hilm. 11. 
Jika masalah di daerah-daerah itu sampai saat ini seolah belum terselesaikan, siapakah yang harus bertanggung jawab? Secara prinsipiil, UUD 1945 menyatakan bahwa concentration of power and responsibility upon the president. Oleh karena itu, secara makro hal itu merupakan tanggung jawab Presiden tidak dapat begitu saja dibebaskan dibebaskan dari tanggung jawab karena tugas itu sudah dilimpahkan kepada dirinya, sehingga wajar kalau tanggung jawab harus dipikul juga oleh Wakil Presiden.

Untuk tebih mempertegas pernyataan Presiden pada Sidang Tahunan MPR tersebut, pemerintah mengeluarkan Keputusan Presiden No. 121 Tahunan 2000 tentang Penugasan Presiden kepada Wakil Presiden untuk Melaksanakan Tugas Teknis Pemerintahan Sehari-hari.

Sikap Presiden Abdurrahman Wahid yang sifatnya memotong gagasan pembuatan Ketetapan MPR khusus dinilai oleh Moh. Mahfud MD sebagai langkah yang tepat baik secara politik maupun secara konstitusi. ${ }^{4}$ Secara Politik dapat dikatakan, Abdurrahman Wahid melakukan pengalihan kekuasañ itu berdasarkan kekuasaannya sendiri dan bukan karena dipaksa secara sepihak oleh MPR. Ini memberi kesan, Presiden tidak mudah didikte begitu saja oleh MPR. Tindakan dilakukan Abdurrahman Wahid lebih dapat dibenarkan secara konstitusional, sebab yang dilakukan Abdurrahman Wahid bukan memisahkan atau melepaskan kekuasaan pemerintaan negara dari tangan Presiden melainkan menugaskan kepada Wakil Presiden dengan masih tetap di bawah tanggung jawab Presiden sendiri. Jika Wakil Presiden telah ditugasi untuk meminpin tugas teknis pemerintahan, maka gagasan adanya Menteri Pertama atau Menteri Utama menjadi tidak relevan untuk bicarakan, sebab pemosisian Wakil Presiden sebagai pelaksanaan pimpinan teknis pemerintahan sehari-hari merupakan jawaban yang lebih pas secara politis atas persoalan yang menjadi dasar munculnya gagasan pengangkatan Menteri Pertama atau Menteri Utama.

Sebagaimana telah dibahas di atas, Ketetapan MPR No. III/MPR/1978 tentang Kedudukan dan Hubungan Tata Kerja Lembaga Tertinggi Negara dengan/atau Antar Lembaga-lembaga Tinggi Negara, Pasal 8 Ayat (2) menyatakan, Hubungan kerja antara Presiden dan Wakil Presiden di atur dan ditentukan oleh Presiden dibantu oleh Wakil Presiden. Ketentuan tersebut merupakan pijakan yuridis yang kuat untuk menentukan kerangka kerja antara Presiden dan Wakil Presiden, sebagaimana yang kemudian dituangkan ke dalam Keputusan Presiden No. 121 Tahun 2000. Adapun substansi tugas apa saja yang diberikan oleh Presiden kepada Wakil Presiden tentu merupakan kewenangan Presiden dan hasil kesepakatan kedua belah pihak. Isi Keppres No. 121 Tahun 2000 antara lain menyebutkan tugas Wakil Presiden sebagai berikut:

\section{Pasal 2}

a. Menyusun program dan agenda kerja kabinet serta menentukan fokus dan prioritas kebijakan pemerintahan;

${ }^{4}$ Kompas. 24 Agustus 2000. 
b. Memimpin sidang kabinet, menyimpulkan hasilnya dan menjelaskannya untuk diketahui oleh seluruh rakyat;

c. Memberi pengarahan dan petunjuk kepada para anggota kabinet;

d. Memantau, mengawasi dan menilai kinerja para anggota kabinet dalam melaksanakan program dan agenda kerja kabinet;

e. Melakukan koordinasi dengan lembaga tinggi negara lainnya untuk memperlancar tugas penyelenggaraan pemerintahan;

f. Mengambil keputusan operasional dalam rangka pelaksanaan tugas teknis pemerintahan sehari-hari;

g. Menandatangani surat keputusan yang berisi kebijakan penetapan yang telah disetujui oleh Presiden.

\section{Pasal 3}

Surat keputusan sebagaimana dimaksud dalam Pasal 2 huruf (g), meliputi;

a. Keputusan tentang struktur organisasi departemen dan lembaga pemerintahan non departemen;

b. Keputusan tentang pengangkatan para pejabat eselon I dan departemen pemerintahan dan lembaga pemerintahan non departemen, serta jabatan-jabatan dalam struktur organisasi Tentara Nasional Indonesia dan Kepolisian Negara RI yang menurut peraturan perundang-undangan yang berlaku harus dilakukan melalui Keputusan Presiden; c. Keputusan tentàng kenaikan pangkat dan atau pemberhentian/pensiun pegawai negeri sipil perwira Tentara Nasional Indonesia (TNI) dan Kepolisian Negara RI (Poiri) yang menurut peraturan perundang-undangan yang berlaku harus dilakukan melalui Keputusan Presiden;

d. Keputusan pengesahan gubernur sebagaimana telah ditetapkan oleh Dewan Perwakilan Rakyat Daerah Propinsi.

Dari ketentuan Pasal 2 tersebut di atas, nampak bahwa tugas yang diberikan kepada Wakil Presiden ada penambahan yang cukup signifikan dari sebelumnya. Dengan adanya pemberian tugas oleh Presiden kepada Wakil. Presiden sesungguhnya telah terjadi pengurangan kekuasaan Presiden secara konstitusional, meskipun tugas yang diberikan kepada Wakil Presiden belum bersifat substansial. Apabila ternyata ada beberapa pihak yang menilai bahwa tugas yang diberikan kepada Wakil Presiden Megawati yang dituangkan dalam Keppres tersebut kurang substansial, mungkin hal itu dipandang dari sudut politis. Dilihat dari sudut pandang yuridis ketatanegaraan, pengaturan tentang pemberian tugas dari Presiden kepada Wakil Presiden sebagaimana yang diatur dalam Keppres No. 121 Tahun 2000 ditandatangani oleh Presiden Abdurrahman Wahid, Wakil Presiden Megawati Soekarno Putri meminta agar ia tidak diberi wewenang yang terlalu banyak. ${ }^{5}$ Mungkinkah permintaan itu sekedar

${ }^{5}$ Kompas, 28 Agustus 2000. 
basa basi atau merupakan pertimbangan kearifan Wakil Presiden terhadap realitas yang ada. Bahkan pada kesempatan lain Wakil Presiden meminta dukungan seluruh lapisan masyarakat untuk bekerja bersama-sama melaksanakan tugas yang dilimpahkan Presiden kepadanya.

Beberapa kalangan menilai bahwa tugas yang diberikan kepada Wakil Presiden yang tertuang dalam Pasal 2 butir a sampai dengan f sudah cukup bagus, tetapi pada butir $g$ yang berbunyi "Menandatangani surat keputusan yang berisi kebijakan penetapan yang telah disetuiui oleh Presiden" dipandang mengebiri kewenangan yang diberikan kepada Wakil Presiden. Penilaian yang demikian itu tidak sepenuhnya benar, karena bagaimanapun penanggung jawab pemerintahan negara tetap berada di tangan Presiden. Wakil Presiden tidak dapat bertindak sendiri karena ia sematamata merupakan pembantu Presiden.

Secara konstitusional Presiden tetap sebagai kepala pemerintahan yang bertanggung jawab kepada MPR dan Wakil Presiden tidak bisa secara langsung menyampaikan tanggung jawabnya sendiri dalam menyelenggarakan pemerintahan negara kepada MPR.

\section{Pertanggungjawaban Wakil Presiden}

Munculnya tuntutan supaya pelimpahan tugas Presiden kepada Wakil Presiden dituangkan dalam Ketetapan MPR, justru akan memunculkan masalah baru yang berkaitan. dengan pertanggungjawaban Wakil Presiden, perlukah Wakil Presiden memberikan pertanggungjawaban? Kepada siapakah Wakil Presiden harus bertanggung jawab?

Berdasarkan Pasal 4 ayat (2) dan Pasal 6 ayat (2) UUD 1945 dapat ditarik beberapa alternatif pertanggungjawaban, antara lain: pertama, Wakil Presiden bertanggung jawab kepada MPR, atas dasar dipilih oleh MPR; kedua, Wakil Presiden bertanggung kepada Presiden; ketiga, Wakil Presiden bertanggung jawab baik kepada Presiden maupun kepada MPR, atas dasar di satu pihak ia pembantu Presiden, di lain pihak ia dipilih oleh MPR. ${ }^{6}$

Altematif pertama, apabila Wakil Presiden bertanggung jawab kepada MPR, maka konsekuensinya akan mengakibatkan timbulnya dua pertanggungjawaban eksekutif yang seolah-olah terpisah. Padahal menurut penjelasan UUD 1945 telah ditegaskan "Dalam menjalankan Pemerintahan Negara, kekuasaaan dan tanggung jawab adalah di tangan Presiden (concentration of power and responsibility upon the President).

Alternatif kedua, Wakil Presiden bertanggung jawab kepada Presiden atas dasar merupakan pembantu Presiden, mempunyai beberapa kelemahan, yaitu: pertama, dengan maksud apa wakil Presiden dipilih oleh MPR serta harus mengucapkan sumpah atau janji sebelum memegang jabatannya di hadapan MPR atau DPR. Sedangkan pertanggungjawabannya (hanya) kepada Presiden. Mengapa tidak dipilih (dan atau diangkat) oleh Presiden saja, dengan konsekuensi dapat diberhentikan oleh Presiden. Kedua, beban pertanggungjawaban

'Bagir Manan dan Kuntana Magnar. 1993. Beberapa Masalah Hukum Tatanegara Indonesia. Bandung:Alumni. Hlm.29. 
Presiden kepada MPR menjadi bertambah berat, karena selain harus mempertanggungjawabkan setiap kebijaksanaannnya, juga harus memikul tanggung jawab (tindakan) Wakil Presiden.

Mengapa Wakil Presiden tidak dipilih saja oleh Presiden, hal ini dimaksudkan untuk menunjukkan perbedaaan kedudukan Wakil Presiden dengan Menteri-menteri selaku pembantu Presiden. Di samping itu, juga untuk memenuhi kebutuhan yuridis Pasal 8 UUD 1945 jo Ketetapan MPR No. VII/MPR/1973 tentang keadaaan Presiden dan Wakil Presiden RI Berhalangan, Pasal 2 ayat (1) menyatakan sebagai berikut: "Dalam hal Presiden berhalangan tetap, maka ia diganti oleh Wakil Presiden sampai habis masa jabatannya". Pasal 8 UUD 1945 jo Pasal 2 ayat (1) Ketetapan MPR No. VII/MPR/1973 ini berkaitan erat dengan Pasal 6 ayat (2) UUD 1945, yakni tentang keadaaan Presiden dan Wakil Presiden dipilih oleh MPR dengan suara yang terbanyak. Apabila Wakil Presiden dipilih oleh Presiden, dan ternyata di tengah jalan Presiden berhalangan (tetap), maka dapatkah Wakil Presiden secara otomatis mengganti kedudukan 'Presiden? Tidakkah persoalan ini nantinya akan terganjal oleh ketentuan Pasal 6 ayat (2) UUD 1945. Untuk keperluan Penggantian kedudukan Presiden (yang berhalangan) tentu harus dilakukan pemilihan baru oleh MPR, karena Wakil Presiden tidak dipilih oleh MPR. Hal ini tentu akan berbeda manakalah Wakil Presiden dipilih oleh MPR, sehingga apabila Presiden berhalangan (tetap) Wakil Presiden dapat secara otomatis mengganti kedudukan Presiden.

Alternatif ketiga, Wakil Presiden. bertanggung jawab baik kepada. Presiden maupun kepada MPR, atas dasar di satu pihak ia pembantu Presiden dan di lain pihak ia dipilih oleh MPR.

Sesungguhya wajar kalau Wakil Presiden bertanggung jawab kepada MPR, karena ia dipilih dan diangkat oleh MPR. Membebaskan Wakil Presiden dari suatu sistem pertanggungjawaban adalah menyalahi prinsip pemerintahan negara demokrasi. Dalam negara demokratis, setiap jabatan atau pejabat harus ada pertanggungjawaban dan tempat bertanggung jawab, namun UUD ataupun Ketetapan MPR tidak mengatur masalah pertanggungjawaban + Wakil Presiden. Bagaimana MPR akan melakukan penilaian terhadap kinerja Wakil Presiden kalau tidak ada aturan main yang jelas. ${ }^{7}$

Dalam praktik ketatanegaraan; meskipun Wakil Presiden dipilih oleh MPR tetapi MPR tidak pernah memberikan tugas khusus kepada Wakil Presiden, sehingga apa yang harus dipertanggungjawabkan oleh Wakil Presiden kepada MPR menjadi kabur. Selama ini tugas Wakil Presiden diberikan oleh Presiden, sehingga logis kalau Wakil Presiden bertanggung jawab kepada Presiden. Sebagaimana yang selama ini disaksikan dalam Sidang Umum MPR, hanya Presiden yang memberikan pertanggungjawaban di akhir masa jabatannya kepada MPR. Dengan kata lain, pertanggungjawaban Wakil Presiden Him. 47.

7Bagir Manan. 1999. Lembaga Kepresidenan. Pusat Studi Hukum Faultas Hukum Ull dan Gama Media. 
hanya kepada Presiden. Hal ini lebih dipertegas lagi setelah dikeluarkannya Keputusan Presiden No.121 Tahun 2000.

Kembali pada persoalan yang dibahas di atas, yakni Pasal 2 butir (g) Keppres No. 121 Tahun 2000, hal itu tentu dimaksudkan dalam kerangka penjelasan UUD 1945 butir IV, bahwa Presiden ialah penyelenggara Pemerintahan Negara yang tertinggi di bawah Majelis dan dalam menjalankan pemerintahan Negara, kekuasan dan tanggung jawab adalah di tangan Presiden.

Belakangan muncul ungkapan kekecewaan dari beberapa Anggota DPR terhadap Keppres No. 121 Tahun 2000 yang juga dikaitkan dengan susunan kabinet yang baru saja dilantik adalah dominasi pilihan orang-orang pilihan Presiden Abdurrahman Wahid (All the President Man), sehingga secara politis mereka akan lebih loyal kepada Presiden Abdurrahman Wahid daripada kepada Megawati, sementara dalam melakukan pekerjaaannya mereka akan lebih banyak berhubungan dengan Wakil Presiden Megawati. Ungkapan seperti itu sebaiknya dihindari, karena akan menimbulkan kesan negatif terhadap kredibilitas dan kapabilitas seseorang. Seolah-olah menteri-menteri itu tidak punya loyalitas terhadap bangsa dan negara, loyalitasnya hanya kepada atasan (Presiden). Bukankah loyalitas tunggal sudah disingkirkan melalui gerakan reformasi, kita tidak ingin terjebak pada keadaan yang sama dengan Orde Baru. Patut dingat, bahwa ketika seseorang sudah mendapat amanah dari rakyat entah itu jabatan sebagai Presiden, Wakil Presiden maupun Menteri dan lain-lain, seyogyanya ia mengabdi tidak lagi kepada atasannya semata-mata tetapi lebih tinggi lagi, ia harus mengabdi untuk kepentingan bangsa dan negara. Sehingga segala tindakannya tidak cukup hanya dapat dipertanggungjawabkan kepada atasannya saja, tetapi juga harus dapat dipertanggungjawabkan kepada seluruh rakyat Indonesia.

Kalau penilaian sementara kalangan itu benar bahwa dengan susunan kabinet yang baru Wakil Presiden merasa akan mengalami kesulitan untuk melaksanakan Keppres No. 121 Tahun 2000, tentu Wakil Presiden dapat memanfaatkan stafnya di jajaran Sekretaris Wakil Presiden untuk membantu secara bersama-sama untuk menjalankan tugas yang sudah dilimpahkan kepadanya. Sikap proaktif Wakil Presiden pastilah diharapkan oleh semua kalangan, dengan segala kearifan yang dimiliki, selama ini masyarakat yakin bahwa kabinet ini akan bejjalan sesuai dengan yang diharapkan oleh seluruh lapisan masyarakat.

Jika peran baru itu dapat dimainkan secara atraktif, maka kinerja pemerintahan diharapkan dapat lebih baik. Setidaknya merupakan awal perbaikan kondisi bangsa untuk keluar dari krisis, sekaligus Megawati sendiri akan memperoleh investasi politik yang cukup berharga dalam percaturan politik di negeri ini. Sebaliknya, jika Megawati tidak menggunakan peluang politik itu dengan seksama, maka dirinya selain akan dinilai benar-benar tidak mampu sebagaimana keraguan banyak pihak selama ini, pada saat yang sama akan memperoleh getah politik yang harus diterima sebagai konsekuensi dari penerimaan mandat politik itu. ${ }^{8}$ Keppres No. 121 Tahun 2000 cukuplah dipandang

घhaedar Nashir. "Megawati Dipersimpangan Jalan”. Republika. Sabtu. 2 September 2000. Hilm. 18. 
sebagai ujian apakah Wakil Presiden beserta para Menteri mampu untuk melaksanakannya atau gagal melaksanakannya. Apabila hasilnya menggembirakan, maka perlu untuk ditingkatkan lagi pada masa yang akan datang. Jika terjadi yang sebaliknya, maka Presiden harus segera melakukan antisipasi yang lebih baik lagi dalam menyusun kabinet maupun skala prioritas program.

\section{Simpulan}

Guna mengatasi persoalan di seputar kelemahan manajerial pemerintahan Presiden Abdurrahman Wahid dan Cap Wakil Presiden hanya sebagai "ban serep", dikeluarkan Keppres 121 Tahun 2000, tentang Penugasannya Presiden kepada Wakil Presiden untuk Melaksanakan Tugas Teknis Pemerintahan Sehari-hari, merupakan langkah strategis dan urgen. Keputusan politis dan konstitutif presiden melalui Keppres ini, dianggap lebih tepat, mengingat 2 hal: pertama, bahwa penyerahan tugas teknis pemerintahan presiden kepada Wakil Presiden hanya merupakan porsi internal sebagaimana diatur dalam Pasal 4 ayat (1) dan (2), dan Pasal 8 UUD 45; kedua untuk mempertegas kembali sistem pemerintahan presidensial yang dianut konstitusi (Penjelasan UUD 1945 Butir IV).

Sementara kekhawatiran yang muncul di kalangan anggota MPR akan inkonsistensi Presiden terhadap keputusannya tersebut sehingga harus diperkuat dengan bajuTap MPR, tampaknya kurang tepat, sebab di samping substansi tersebut bukan merupakan kewenangan MPR, juga diangap menyalahi konstitusi yakni sistem pemerintahan presidensial yang diatur dalam penjelasan UUD 1945 Butir IV.
Berkaitan dengan persoalan di atas, hal ini sebenarnya mengindikasikan bahwa masih banyak kekosongan hukum dan perlunya memikirkan kembali bentuk ideal dari sistem pemerintahan yang dapat menjawab dinamika ketatanegaraan pada konteks kini dan mendatang. $\square$

\section{Daftar Pustaka}

Alrasid, Harun. Jabatan Presiden Rl, Sebuah Tinjauan Hukum Tata Negara. Pidato Dies Rede pada Sidang Sènat Terbuka Dalam Rangka Dies Natalis Ke-56 Univesitas Islam Indonesia Yogyakarta. Tanggal 8 November 1999.

Huda, Ni'matul. 1999. Hukum Tata Negara, Kajian Teoitis dan Yuridis Terhadap Konstitusi Indonesia. Yogyakarta: Pusat Studi Hukum FH Ull dan Gama Media.

Manan, Bagir dan Kuntanà Magnar. 1993. Beberapa Masalah Hukum Tatanegara Indonesia. Bandung: Alumni.

Manan, Bagir. 1999. Lembaga Kepresidenan. Pusat Studi Hukum Fakultas Hukum UII dan Gama Media.

Nashir, Haedar. "Megawai Dipersimpangan Jalan". Republika. Sabtu. 2 September 2000. HIm. 18.

Forum Keadilan. №. 20. 20 Agustus 2000

Kompas. 24 Agustus 2000

Kompas, 28 Agustus 2000 


\title{
Independensi dan Peran Mahkamah Agung (Kajian Dari sudut Pandang Yuridis Ketatanegaraan)
}

\author{
Dahlan Thaib
}

\begin{abstract}
To provide the necessity of formal prerequisite of legal nation, the independency of the judicial power is explicilly put on the 1945 Constitution, which is elaborated in the govemment regulations. In fact, the freedom and independency of the judicial power are meaningless if it is not followed by Supreme Court rights to examine the legal materials toward regulations actively. The discussion of the examining rights of the regulation product-material was issued in the proposal to form a Constitution Court in the second amendment plan of the 1945 Constitution prepared by Ad Hoc Committee of the Work Board of General Assembly in its annual session August 2000, which was, however, unaccepted. The regulation as an instrument of state affairs system holds the vital role to arrange and facilitate the ideal affairs among the highest institution, high institution, and societies. Therefore, in order to achieve the imposed goal, the authority of the examining rights of the materials by the Supreme Court should be maximized through the existence of the courts.
\end{abstract}

\section{Pendahuluan}

Sejak awal kemerdekaan, the founding fathers (para pendiri) negara kesatuan Republik Indonesia, telah memiliki komitmen kuat mewujudkan kekuasaan kehakiman yang bebas dalam sistem ketatanegaraan Indonesia. Komitmen ini secara tegas tercantum dalam penjelasan Pasal 24 dan 25 UUD 1945 yang menyatakan, kekuasaan kehakiman ialah kekuasaan yang merdeka, artinya terlepas dari pengaruh kekuasaan pemerintah. Berhubung dengan itu harus diadakan jaminan dalam undang-undang tentang kedudukan para hakim.
Komitmen tersebut merupakan perwujudan tekad para pendiri negara untuk menjadikan Indonesia sebagai negara hukum modern, yang menganut kaedah-kaedah paham negara modem yang konstitusional.

Namun dalam praktik ketatanegaraan, khususnya pada masa Orde Baru kemandirian itu telah direduksi UU No.14 Tahun 1985 tentang Mahkamah Agung dan UU No.14 Tahun 1970 tentang Pokok Kekuasaan Kehakiman yang dibuat oleh pemerintah dan DPR. Di samping itu kenyataan yang tidak terbantahkan kemandirian peradilan juga diperlemah dengan adanya praktik korupsi, kolusi dan nepotisme (KKN). 
Karenanya kemandirian kekuasaan kehakiman atau kemandirian Mahkamah Agung tidak hanya menyangkut masalah sistem perundang-undangan yang mengatur MA, tetapi juga dipengaruhi praktik KKN yang merajalela dikalangan para hakimnya. Praktik KKN di MA berakibat tidak adanya kepastian hukum. Tidaklah berlebihan apabila reformasi di lembaga negara MA harus dimulai dari orangorang yang kini menjadi hakim agung.

Sidang Umum Tahunan (SUT) MPR tanggal $7 \mathrm{~s} / \mathrm{d} 18$ Agustus 2000 yang salah satu agendanya adalah amandemen UUD 1945 karena keterbatasan waktu belum dapat mengubah ketentuan konstitusi mengenai kekuasaan kehakiman. Namun penundaan amandemen beberapa pasal UUD 1945 khususnya Pasal 24 dan 25 mengenai kekuasaan kehakiman adalah putusan yang lebih baik dari kaca mata pandang konstitusi, karena amandemen atau perubahan UUD memerlukan pemikiran yang mendalam dan pertimbangan yang masak. ${ }^{1}$

Oleh karena itu diskursus tentang kemandirian kekuasaan Mahkamah Agung akan terus bergema sampai dengan di amandemen atau perubahan ketiga UUD 1945 pada Sidang Umum Tahunan MPR berikutnya.

\section{Kekuasaan Kehakiman} dalam Pandangan Konstitusi

Pembahasan mengenai independensi atau kemandirian dan peran lembaga yudikatif atau Mahkamah Agung tidak dapat dilepaskan dari ketentuan-ketentuan tentang sistem ketatanegaraan yang diatur oleh konstitusi.

Dari konstitusi atau undang-undang dasar suatu negara, akan diketahui tentang negara itu baik bentuk, susunan negara maupun sistem pemerintahannya. ${ }^{2}$ Dalam sistem politik ketatanegaraan Indonesia tidak dianut ajaran pemisahan kekuasaan (separation of power) Trias Politica, sebagaimana dikemukakan oleh Montesquieu, tetapi menganut sistem pembagian kekuasaan (distribution of power). Ini berarti ada perimbangan kekuasaan antara lembaga legislatif, eksekutif, dan yudikatif.

Sebagaimana diketahui, Sistem Ketatanegaraan Indonesia berdasarkan UUD 1945 menegaskan bahwa kedaulatan atau kekuasaan negara tertinggi ada di tangan rakyat, yang dilaksanakan sepenuhnya oleh Majelis Permusyawaratan Rakyat (Pasal 1 ayat (2)). Rumusan kedaulatan adalah di tangan rakyat menunjukkan bahwa kedudukan rakyatlah yang paling sentral dalam sistem ketatanegaraan Indonesia. Namun karena seluruh rakyat Indonesia tidak mungkin berkumpul seluruhnya pada satu saat dan pada satu tempat untuk bermusyawarah mengenai pemerintah/kenegaraan, maka kedaulatan yang ada di tangan rakyat tersebut dilakukan sepenuhnya oleh MPR. Dalam praktik ketatanegaraan, MPR tidak melaksanakan sendiri seluruh kekuasaannya, tetapi kekuasaan tersebut didistribusikan atau didelegasikan kepada lembaga-lembaga tinggi negara di bawahnya. Kekuasaan

${ }^{1}$ K.C. Wheare. 1975. Modern Constitutions. London: Oxford University Press. New York: Toronto. Hilm. 83.

${ }^{2}$ Sri Soemantri. 1987. Prosedur dan Sistem Perubahan Konstitusi. Bandung: Alumni. Hlm. 1-2. 
eksekutif dijalankan oleh Presiden, kekuasaan legislatif dijalankan oleh Presiden bersama DPR, dan kekuasaan yudikatif dijalankan oleh MA. Di samping kekuasaan legislatif, eksekutif, dan yudikatif, maka dalam sistem ketatanegaraan Indonesia masih ditemui kekuasaan konsultatif yang oleh MPR didelegasikan kepada DPA dan kekuasaan inspektif (pengawasan) yang dilimpahkan kepada DPR dan BPK, dalam hal ini DPR melaksanakan fungsi pengawasan dalam bidang politik pemerintah, sedangkan BPK'melaksanakan fungsi pengawasan pada bidang penggunaan anggaran negara.

Namun, tidak berarti bahwa setelah MPR mendistribusikan atau mendelegasikan kekuasaan kepada lembaga-lembaga negara lainnya, MPR tidak mempunyai kekuasaan lagi. Bagaimanapun, kekuasaan itu tetap ada. Sisa kekuasaan yang dijalankan sendiri oleh MPR yang diatur dalam sistem ketatanegaraan, yaitu menetapkan UUD dan GBHN (Pasal 3 UUD 1945), memilih Presiden dan Wakil Presiden (Pasal 6 ayat (2) UUD 1945), mengubah UUD (Pasal 37 UUD 1945) dan tempat Presiden bertanggung jawab (Penjelasan UUD 1945, Butir IV). Sistem demikian merupakan pembagian kekuasaan (distribution of power) atau menurut Ivor Jennings disebut separation of power dalam arti formal. Dengan meminjam teori Jennings, pada umumnya pemisahan kekuasaan dalam arti material tidak terdapat dan bahkan tidak pernah dilaksanakan di Indonesia. Atau dengan perkataan lain, di Indonesia terdapat pembagian kekuasaan dengan tidak menekankan kepada pemisahannya. $^{3}$
Dengan dianutnya konsep atau sistem pembagian kekuasaan tersebut, maka dalam sistem ketatanegaraan Indonesia antara lembaga-lembaga negara di bawah MPR kedudukannya sederajat. Kesederajatan tersebut memberikan fungși pada lembaga tertentu seperti misalnya DPR dan BPK sebagai pengawas terhadap Presiden, fungsi pertimbangan atau penasehat DPA terhadap Presiden dan MA dapat memberikan pertimbangan-pertimbangan hukum kepada lembaga-lembaga tinggi negara lainnya. Pengalaman membuktikan bahwa dalam praktik ketatanegaraan, pelaksanaan fungsi dan tugas masing-masing lembaga negara tersebut sering menimbulkan konflik antar lembaga negara. Pada era Orde Baru misalnya, yang paling banyak menimbulkan permasalahan adalah pelaksanaan tugas antara DPR dan Presiden. Di satu pihak, masih dominannya Presiden dalam proses penyelenggaraan negara sementara DPR sangat lemah dan terkesan hanya sebagai stempel atau legitimasi bagi eksekutif. Dan sebaliknya pada era reformasi dewasa ini posisi Presiden atau eksekutif bila dibandingkan dengan DPR cenderung lebih lemah, hal ini dapat kita saksikan dengan keberhasilan DPR menekan Presiden dalam berbagai bidang, antara lain misalnya mempergunakan hak interpelasi pada bulan Juli 2000 yang telah Ialu. Di samping apa yang dikemukakan di atas, maka persoalan lainnya pada masa orde baru adalah terjadinya penyimpangan dalam pelaksanaan kekuasaan yudikatif atau kekuasaan kehakiman dengan menempatkan kekuasaan

${ }^{3}$ Ismail Suny. 1985. Pembagian Kekuasaan Negara. Jakarta: Aksara Baru. Hlm.6-7 
yudikatif atau kekuasaan kehakiman di bawah kekuasaan eksekutif. ${ }^{4}$ Sehingga banyak kasus penyimpangan dalam pelaksanaan kekuasaan yudikatif, ketidakadilan penegakan hukum, pengadilan yang. sering berpihakkepada penguasa dalam kasus pelanggaran hak warga negara seperti misalnya "surat sakti" MA semasa dipimpin Soerjono dalam kasus tanah adat Hanoch Hebe Ohee dan Kedung Ombo. Dapat dibayangkan betapa runyamnya penegakan hukum di negara tercinta ini bila hakim agung yang ada di MA masih menghambakan diri pada uang dan kekuasaan ketimbang keadilan. Kendatipun pada era reformasi sekarang ini MPR telah mengeluarkan Ketetapan Nomor XI/MPR/ 1998 tentang Pokok Reformasi Pembangunan Dalam Rangka Penyelamatan dan Normalisasi Kehidupan Nasional sebagai Haluan Negara yang antara lain menegaskan periunya pemisahan tegas antara kekuasaan yudikatif dan eksekutif dan selanjutnya Tap tersebut dijabarkan oleh UU No.35 Tahun 1999, namun beberapa pertanyaan mendasar masyarakat tentang kemandirian lembaga yudikatif dan penegakan hukum di indonesia tetap harus digarisbawahi, yakni ketidakpercayaan masyarakat terhadap lembaga peradilan, kinerja aparat penegak hukum (hakim, jaksa, polisi dan pengacara) serta intervensi eksekutif atau pemerintah terhadap lembaga yudikatif atau kekuasaan kehakiman beserta perangkatnya. Untuk menjawab pertanyaan tersebut, maka ke depan harus dilakukan upaya-upaya konkret agar keadaan tidak bertambah parah, misalnya dengan jalan memperbaiki sistem yakni mengamandemen Pasal 24 UUD 1945 di samping perlunya kemauan politik pengambil keputusan untuk ikut memperdayakan kekuasaan kehakiman.

Independensi dan Peran Mahkamah Agung

Masalah independensi atau kemandirian lembaga yudikatif atau kekuasaan kehakiman sebagaimana dikemukakan di atas pada masa sekarang sudah menjadi tuntutan masyarakat. Pada masa Orde Baru, tidak ada kemandirian lembaga yudikatif di Indonesia karena lembaga yudikatif (pengadilan) menjadi bagian dari eksekutif. Pada waktu membahas. RUU No. 14 Tahun 1970, gagasan agar pembinaan dan pengawasan kekuasaan kehakiman berada dalam satu atap saja, yaitu di bawah naungan Mahkamah Agung, sudah' pernah menjadi bahan perdebatan yang cukup seru. Gagasan tersebut menjadi pupus karena pihak eksekutif dalam hal ini Menteri Kehakiman pada waktu itu tetap bersikukuh pada pendiriannya, sehingga lahirlah Pasal 11 ayat (1) UU No. 14 Tahun 1970, yang menentukan bahwa kekuasaan kehakiman yang dilakukan oleh empat lingkungan peradilan secara organisatoris, administratif, dan finansial ada di bawah kekuasaan masingmasing departemen yang bersangkutan.

Berkaitan dengan independensi atau kemandirian kekuasaan yudikatif, sebenarnya masalah tersebut sudah diatur secara konstitusional dalam Pasal 24 dan 25 UUD

4Pasal 11 ayat (1) UU No. 14 Tahun 1970 yang menentukan bahwa kekuasaan kehakiman yang dilakukan oleh keempat lingkungan peradilan selaku organisatoris, administratif dan finansial ada di bawah kekuasaan masing-masing Departemen yang bersangkutan. 
1945 yang menegaskan bahwa kekuasaan kehakiman dilakukan oleh sebuah Mahkamah Agung dan lain-lain Badan-badan Kehakiman menurut UU. Susunan dan Kedudukan Badanbadan Kehakiman tersebut diatur dengan UU.

Terhadap kedua pasal tersebut, yakni Pasal 24 dan Pasal 25 pembentuk UUD 1945 memberikan penjelasan yang sangat penting, yaitu bahwa "kekuasaan kehakiman ialah kekuasaan yang merdeka, terlepas dari pengaruh kekuasaan pemerintah." Dalam Pasal 2 UU No. 14 Tahun 1985 tentang "kebebasan" MA ditambah lagi rumusan, "...pengaruh kekuasaan pemerintah dan pengaruh lain-lainnya." Yang dimaksud "pengaruh-pengaruh lainnya" di antaranya ialah pers dan lembaga-lembaga di luar kekuasaan kehakiman. ${ }^{5}$ Tuntutan akan perlunya kekuasaan kehakiman yang bebas dan terlepas dari pengaruh kekuasaan eksekutif dan pengaruh kekuasaan lainnya adalah tuntutan yang selalu bergema dalam kehidupan politik ketatanegaraan Indonesia, sejak kurun waktu Orde Lama, Orde Baru sampai dengan Orde Reformasi dewasa ini. Betapa pentingnya kekuasaan kehakiman yang bebas, ini tidak dapat dipisahkan dari ketentuan konstitusional yang menegaskan bahwa Negara Indonesia adalah negara hukum (rechtstaaf), bukan negara kekuasaan (machtstaaf).

Mẹnurut Friedman, negara hukum identik dengan rule of law. Istilah Rechtsaat menurut
Friedman mengandung arti pembatasan kekuasaan negara oleh hukum. ${ }^{6}$ Dipakainya istilah rechtstaat dalam konstitusi Indonesia harus diartikan bahwa hukum atau rechsstaat dipakai sejauh unsur-unsur dalam pengertian tersebut dapat mendukung pandangan bernegara. ${ }^{7}$ Sebagaimana dikemukakan di atas salah satu unsur negara hukum yang ditegaskan dalam konstitusi/UUD 1945 adalah kekuasaan kehakiman, adalah kekuasaan merdeka dari pengaruh eksekutif.

Dari konsepsi negara hukum sebagaimana dikemukakan, khususnya konsepsi negara hukum yang digariskan oleh konstitusi, maka dalam rangka melaksanakan Pasal 24 dan 25 UUD 1945, tidak dapat tidak undang-undang harus secara tegas melarang kekuasaan pemerintahan negara (eksekutif) untuk membatasi atau mengurangi wewenang kekuasaan kehakiman yang merdeka yang telah dijamin oleh konstitusi tersebut. Untuk itu, maka segala sesuatu yang berkaitan dengan rekruitmen para hakim, masalah administrasi dan organisasi termasuk masalah finansial harus menjadi wewenang intern lembaga yudikatif. Dari ketentuan tersebut, lebih lanjut yang perlu dikemukakan adalah bahwa dari sudut pandang hukum tata negara terhadap MA tidak diadakan pengawasan karena MA tidak mengeluarkan kebijakan yang berlaku bagi rakyat.

MA adalah lembaga yudikatif yang mempunyai otonomi, lepas dari kontrol

5Sri Soemantri. "Kemandirian Kekuasaan Kehakiman sebagai Prasyarat Negara Hukum Indonesia." Makalah Seminar 50 Tahun Kemandirian Kekuasaan Kehakiman di indonesia. Diselenggarakan UGM. Yogyakarta, tanggal 26 Agustus 1995.

${ }^{6}$ Friedman. 1960. Legal Theory. London: Stern \& Sou Limited. HIm. 456.

7Padmo Wahyono. 1982. Negara Republik Indonesia. Jakarta: Penerbit Rajawali. HIm. 17. 
eksekutif dan DPR. Hal ini perlu dikemukakan karena pernah ada usulan agar DPR diberi wewenang untuk memanggil atau meminta keterangan kepada MA berkaitan idengan penegakan hukum. Dasar pemikirannya pada waktu itu adalah Hakim Agung diusulkan oleh DPR sehingga sudah sepantasnya jika DPR berwenang meminta keterangan kepada MA manakala terjadi penyelewengan dalam penegakan hukum. Dari sudut pandang hukum ketatanegaraan, usulan tersebut inkonstitusional karena hubungan antara DPR dan MA terpisah, tidak ada kontrol atau saling meminta keterangan satu dengan lainnya. Hubungan partnership dan saling mengontrol dalam sistem ketatanegaraan Indonesia hanya terjadi antara DPR dengan eksekutif.

MA mempunyai otonomi bersifat merdeka dan bebas dari pengaruh (pengawasan) pihak mana pun. Dalam sejarah ketatanegaraan Indonesia ditemukan ketentuan dalam Peraturan Presiden No. 6 Tahun 1946 yang menegaskan tidak ada hubungan antara MA dengan Komite Nasional Pusat yang waktu itu bertindak sebagai parlemen. Peraturan tersebut masih berlaku sehingga dapat diterapkan dalam pelaksanaan hubungan MA-DPR sekarang.

Persoalan yang muncul adalah kalau MA bebas dari pengaruh kekuasaan mana pun, maka kekuasaan MA tidak terbatas, dan ini menyalahi prinsip-prinsip konstitusi yang pada hakikatnya mengatur tentang pembatasan kekuasaan. Karena itu pertanyaan yang mendasar adalah siapa yang mengawasi MA dalam sistem ketatanegaraan Indonesia.

Sebagaimana dikemukakan di atas, karena MA tidak mengeluarkan kebijaksanaan yang mengikat rakyat, maka tidak perlu dikontrol. Kalaupun hendak dilakukan pengawasan, maka pengawasan tersebut dari kaca mata hukum ketatanegaraan hanya dapat dilakukan oleh MPR. MPR berhak -meminta pertanggungjawaban MA atas pelaksanaan tugasnya. Dasar pemikirannya, MA menerima pelimpahan kekuasaan dari MPR maka sudah sepantasnya jika MA bertanggung jawab kepada MPR selaku pemegang kekuasaan negara tertinggi, dan hal ini harus dicantumkan secara eksplisit dalam rangka perubahan UUD 1945. Dalam kaitannya dengan pertanggungjawaban MA kepada: MPR maka tambahan amandemen terhadap Pasal 24 dan Pasal 25 UUD 1945 adalah mengganti kata "Undang-Undang" dalam pasal-pasal tersebut dengan kata "Ketetapan Majelis Permusyawaratan Rakyat." Konsekuensinya adalah mencabut semua undang-undang yang telah membuat Mahkamah.Agung (dan lain-lain Badan Kehakiman) tak berdaya dalam melaksanakan tugas dan fungsi serta tanggung jawabnya sebagai pelaku.kekuasaan kehakiman.

Kemudian menggantinya dengan Ketetapan MPR yang sesuai dengan konsepsi tentang-kekuasaan kehakiman . dan Mahkamah Agung (dañ-lain-lain Badan Kehakiman) yang ideal yang mampu menjadi pelaku kekuasaan kehakiman dalam arti yang luas, utuh, dan merdeka terlepas dari pengaruh kekuasaan pemerintah dan kekuasaan lainnya.

Setelah mengalami krisis monoter yang berkepanjangan dan bahkan kemudian menjalar ke krisis ekonomi, politik dan hukum telah mendorong bangsa indonesia untuk melakukan reformasi dalam berbagai bidang kehidupan ketatanegaraan.

Dengan tidak mengabaikan reformasi di bidang politik dan ekonomi, maka dewasa ini 
reformasi di bidang hukum dirasakan paling mendesak. Menurut Hartono Marjono dalam bidang hukum, banyak hal yang dilihat sebagai titik kelemahan yang berakibat fatal. Kelemahan itu antara lain: ${ }^{8}$

a. Tidak jelasnya siapa yang menjadi instansi terakhir yang bertanggung jawab atas lahirnya sebuah RUU.

b. Tidak berfungsinya tugas wewenang dan kekuasaan kehakiman yang dimiliki-oleh Mahkamah Agung karena selama ini Mahkamah Agung hanya menjalankan kekuasaan Peradilan semata.

c. Tidak adanya "Mahkamah Konstitusi" yang berwenang menguji, menentukan dan mengatakan apakah suatu undangundang itu melanggar UUD atau tidak.

d. Lemahnya proses pengundangan serta law enforcement-nya

Di samping apa yang dikemukakan sering juga dikeluhkan tidak adanya kebebasan hakim akibat campur tangan ekstra yudisial. Karena itu dengan keluarnya TAP MPR No. $X$ 1998 tentang Pokok-pokok Reformasi Pembangunan, khususnya bidang hukum yang mengharuskan penjabaran mengenai pemisahan yang tegas antara fungsi-fungsi yudikatif dan eksekutif merupakan peluang yang harus dimanfaatkan untuk memberdayakan lembaga yudikatif di Indonesia.

Pengaturan baru kekuasaan kehakiman yang dilepaskan (dipisahkan) dari kekuasaan pemerintah yang ditegaskan oleh TAP MPR No. X/1998, selanjutnya dijabarkan lebih lanjut oleh UU No. 35 Tahun 1999. Berdasarkan ketentuan tersebut, Departemen Hukum dan Perundang-undangan, sekarang berubah lagi menjadi Departemen Kehakiman dan HAM tidak lagi mengatur dan mengurus keorganisasian administratif, keuangan, dan kepegawaian kekuasaan kehakiman.

Karena itu, yang menjadi pokok perhatian adalah bagaimana menjabarkan pemisahan yang tegas antara fungsi yudikatif dan eksekutif. Dan setelah itu adalah bagaimana penempatan kekuasaan yudikatif (MA) dalam konstelasi kenegaraan. Substansi konstitusi menghendaki pelaksanaan reformasi dan penataan hukum secara nasional, menuntut optimalisasi peranan dan fungsi lembagalembaga negara khususnya MA agar dapat berperan nyata dan aktif di dalamnya.

Sebagai salah satu lembaga negara yang memegang kekuasaan yudikatif, MA adalah lembaga yang berfungsi sebagai penjaga konstitusi, dan karena itu maka seharusnya MA berperan aktif untuk menjaga kepastian konstitusi (hukum) dengan hak menguji ( Judicial Review) terhadap Undang-Undang dan peraturan di bawahnya yang dilakukan secara aktif.

Peran aktif MA dalam melakukan Judicial Review adalah dalam upaya ikut mewujudkan reformasi di bidang hukum. Selama Orde Baru tidak mungkin dilakukan Judicial Review terhadap Undang-Undang karena MA hanya berwenang menguji terhadap peraturan perundang-undangan yang berada di bawah Undang-Undang (Pasal 26 ayat (1) UU No. 14 Tahun 1970 jo TAP MPR No. IIII MPR/1978 Pasal 11 ayat (4)).

${ }^{8}$ Hartono Marjono. 1998. Reformasi Politik suatu Keharusan. Jakarta: Gema insani Press. HIm. 75. 
Pengujian terhadap UU lebih esensial dan berdampak prinsipal dalam mengontrol konstitusionalitas produk legislatif agar tidak bertentangan dengan konstitusi dan hak-hak asasi manusia khususnya hak asasi di bidang politik. Dengan kompetensi Judicial Review yang dimiliki MA maka akan tercipta mekanisme check and balance (keseimbangan kekuasaan) dengan cabang kekuasaan lain khususnya eksekutif dan legislatif dalam sistem ketatanegaraan Indonesia mendatang.

Sebagaimana diketahui bahwa dalam sejarah ketatanegaraan indonesia Sidang Umum Tahunan (SUT) MPR yang diselenggarakan untuk pertama kalinya pada bulan Agustus tahun 2000 yang telah lalu, terungkap keinginan untuk membentuk Mahkamah Konstitusi di lingkungan Mahkamah Agung (MA). Menurut Rancangan Perubahan Kedua UUD 1945 yang telah disiapkan oleh panitia Ad Hoc (PAH) Badan Pekerja (BP) MPR untuk dibahas dalam Sidang Umum Tahunan MPR, rumusan tentang hal tersebut tercantum dalam Pasal $25 \mathrm{~B}$, Bab IX tentang kekuasaan kehakiman dan Penegakan Hukum. Namun sangat disayangkan, bab ini kemudian termasuk bab yang telah dibahas tapi tidak mendapat kesepakatan. Dalam rancangan perubahan kedua ini, Mahkamah Konstitusi direncanakan mempunyai kewenangan untuk menguji secara material atas undang-undang, memberikan putusan atas pertentangan antara undang-undang, memberikan putusan atas persengketaan kewenangan antara Lembaga Negara, antara pemerintah pusat dengan pemerintah daerah dan antar pemerintah daerah. Putusan Mahkamah konstitusi merupakan putusan tingkat pertama dan terakhir.
Selanjutnya Pengadilan atau Mahkamah Konstitusi ini dijadikan lingkungan kelima dari macam-macam lingkungan peradilan seperti peradilan umum, peradilan agama, peradilan militer dan peradilan tata usaha negara di Mahkamah Agung.

Gagalnya pembahasan tentang pembentukan mahkamah konstitusi di lingkungan Mahmakah Agung (MA) dalam rancangan perubahan kedua UUD 1945 pada Sidang Umum Tahunan MPR bulan Agustus 2000 yang lalu patut disesali, karena tuntutan mengenai pentingnya pengadilan konstitusi telah lama bergaung dalam kehidupan ketatanegaraan Indonesia.

Oleh karena itu berdasarkan ketentuan Pasal 5 ayat (1) Ketetapan MPR Nomor III Tahun 2000 tentang Sumber Hukum dan Tata Urutan Perundang-undangan yang disiapkan untuk mengganti TAP MPRS No.XXMPRSI 1966, MPR akan memiliki kewenangan untuk menguji UU ternadap UUD dan Perubahannya, dan TAP MPR. Sedangkan MA berdasarkan ketentuan Pasal 5 ayat (2)TAP MPR Nomor IIII 2000 berwenang untuk menguji peraturan perundang-undangan di bawah undang-undang.

Kehadiran Pasal 5 ayat (1) TAP MPR No.Ill MPR 2000 pada satu sisi merupakan angin segar dalam kehidupan ketatanegaraan Indonesia dalam rangka menciptakan keteraturan dan konsistensi materi peraturan perundangundangan, khususnya antara UU, UUD 1945 dan TAP MPR. Namun demikian dari aspek yuridis ketatanegaraan memang muncul pertanyaan apakah wajar MPR yang selama ini diklarifikasikan sebagai salah satu lembagà legislatif di tingkat pusat diberikan wewenang untuk melakukan pengujian terhadap undangundang? 
Dari sudut pandang Hukum Tata Negara Indonesia kewenangan MPR menguji UU terhadap UUD dimungkinkan karena dalam sistem ketatanegaraan Indonesia MPR dalam kedudukannya sebagai pelaku kedaulatan rakyat memang berwenang untuk melakukan hak menguji material UU terhadap UUD, namun lebih tepat jika hal itu dalam praktik ketatanegaraan yang akan datang dilakukan khusus oleh Mahkamah Konstitusi (constitutional court). Para anggota mahkamah konstitusi harus memiliki kemampuan dan kepakaran yang handal di bidang hukum, khususnya ilmu perundang-undangan dan teknik perancangan peraturan perundang-undang.

Realitas di negara-negara maju pada umumnya memberikan hak menguji material secara aktif kepada MA ataú suatu badan khusus yang melakukan fungsi tersebut. Misalnya, dalam praktik ketatanegaraan di Perancis, ditemukan suatu lembaga yang bernama Conseil Constitutionnel yang mempunyai kewenangan menguji UU, manakala butir-butir yang ada dalam UU bertentangan dengan konstitusi, atau sudah tidak relevan lagi dengan rasa keadilan dapat diajukan gugatan terhadapnya.

Salah satu cara atau mekanisme yang memungkinkan untuk menguji sebuah RUU dalam praktik ketatanegaraan yang akan datang, ialah ketentuan imperatif yang mengharuskan presiden sebelum mengesahkan sebuah RUU yang telah disetujui oleh Presiden dan DPR, untuk terlebih dahulu meminta pertimbangan MA untuk diuji apakah isi UU tersebut bertentangan atau tidak dengan konstitusi/peraturan yang lebih tinggi dan rasa keadilan.

\section{Simpulan}

Dari hal-hal di atas dapat disimpulkan bahwa Kekuasaan kehakiman yang bebas dan mandiri kurang bermakna jika tidak disertai dengan kewenangan MA untuk menguji material secara aktif terhadap Undang-Undang. Atas dasar pemikiran tersebut, maka perlu terus diperjuangkan ketentuan tentang hak uji material MA pada tingkat Undang-Undang dalam rangka perubahan UUD pada Sidang Umum Tahunan MPR yang akan datang. $\square$

\section{Daftar Pustaka}

Friedman. 1960. Legal Theory. London: Stern \& Sou Limited.

Marjono, Hartono. 1998. Reformasi Politik Suatu Keharusan. Jakarta: Gema Insani Press.

Soemantri, Sri. "Kemandirian Kekuasaan Kehakiman sebagai Prasyarat Negara Hukum Indonesia." Makalah Seminar 50 Tahun Kemandirian Kekuasaan Kehakiman di Indonesia. Diselenggarakan UGM,

Suny, Ismail. 1985. Pembagian Kekuasaan Negara. Jakarta: Aksara Baru.

Thaib, Dahlan. 1999. Kedaulatan Rakyat, Negara Hukum dan Konstitusi. Yogyakarta: Liberty.

Wahyono, Padmo. 1982. Negara Republik Indonesia. Jakarta: Penerbit Rajawali.

Wheare, K.C. 1975. Modern Constitution. London: Oxford University Press. New York: Toronto. 